\title{
Staff Attendance System Using RFID
}

\author{
Muhammad Thariq Abdul Razak", Chuah Chai Wen" \\ Information Security Interest Group (ISIG), Faculty Computer Science and Information Technology, University Tun Hussein Onn Malaysia \\ E-mail:ai130041@siswa.uthm.edu.my,cwchuah@uthm.edu.my
}

\begin{abstract}
Attendance system University Tun Hussien Onn Malaysia is the system to record, and monitor the staff attendance to the daily work. This project is to design develop and implement attendance system using radio frequency identification technology. This technology is divided into two types which are system passive and system active. The proposed system used the system passive to record staff attendance. Frequency identification technology will read the staffs tag and the attendance are recorded automatically and store it in database. The proposed system has several securities feature that can prevent security breaches which is captcha and audit trail. The advantage of proposed system is can differentiate between the human input and robot input and record all the user activity when access to the system.
\end{abstract}

Keywords - Attendance system, Radio frequency identification technology, Captcha, Audit trail.

\section{INTRODUCTION}

Attendance is an action of particular person present on event at work. Attendance can be recorded manually or by using automated system. Manual system uses the paper card to record the staff attendance such as the Bundy Clock a stamping machine. Automated system uses a device to verify the identity of the person such as electronic tags or barcode badges. Faculty of Computer Science and Information Technology (FSKTM) need the attendance system to monitor the staff present in working hours and keep tracks on when the staff are not working.

FSKTM has two categories of staff namely academic staffs and non-academic staffs. Both academic and nonacademic staffs need to record their attendance twice a day. Time recording for academic staffs is flexible. Time recording for non-academic is fixed which is before eight am and after five pm. FSKTM use the Radio Frequency identification (RFID) system passive to record the staff attendances. So that each staff is provided a tag and each tag has their own unique ID.

Every working day, all staff are required to record their attendance by sliding their attendance at the provided machine. All staff require to record their attendance. If any staffs forget to record their attendance more than three time, the staff will be given warning letter. It will give a big impact to the working performance for the staff. For example, not be able to get promotion or increase the salary annually. Hence for those who forgot the record the attendance, they have to provide proof that they had presented. After that, they need to get the approval by the head of department or dean. One major problem is the head of department and dean have to verify the information given by the staff.

The existing system, administrator can only view update add delete and edit the staffs' information and attendance record. If some of the private data has been modified and change by another user, administrator cannot trace which user perform that action. So that this will against the integrity of the data. Data should be altered or modify by the authorized user only. Besides that, when the staff want to access the system user just need username and password to gain authorized access to the system. The attacker can use brute force attack to gain access to the system. The attacker can try and error many time in accessing the existing system. The existing system will not block or freeze the account for the fault tries. Hence there is a need to have a freeze account feature to ensure the security of the system. For example, when the staff enter wrong password more than five times, the system will block the staff account. To activate the account, the staff need to contact the administrator system.

\section{LITERATURE REVIEW}

RFID system consists various components that are connected to one another by a dedicated communication path. As shown in Fig. 1 the components of the RFID technology. Each component is integrated into the system to implement the benefit of RFID solution. The list of components is tag, reader and database [1-3]. 


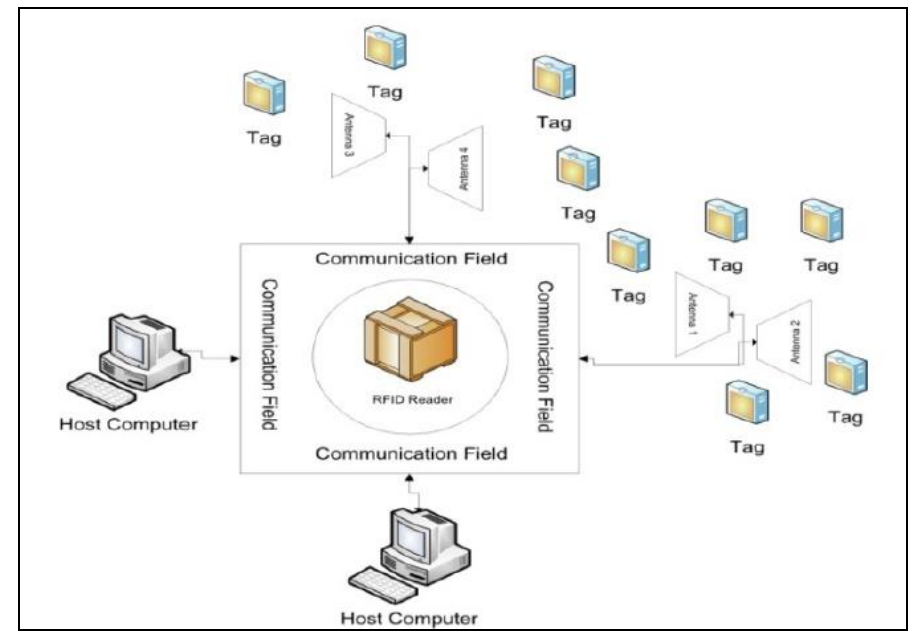

Fig. 1 RFID components [1]

\section{A. Tags}

Tag is the object attached to any product and uses an unique sequence for the tracking of radio waves [1]. The tag consists of a microchip that stores the unique sequence identifier that is useful in identifying objects individually. The sequence is in a numeric serial which is store in the RFID memory. The memory tag can be permanent or re-writable. Table 1 shows the type of tags.

TABLE I

TYPE OF TAGS

\begin{tabular}{|l|l|l|}
\hline \multirow{2}{*}{ Feature } & Type of tags & Active [5] \\
\cline { 2 - 3 } & Passive [4] & Long (20-100 m) \\
\hline Read range & $\begin{array}{l}\text { Short (approximately } \\
17 \mathrm{~m})\end{array}$ & Yes \\
\hline Battery & No & Between 3-5 years \\
\hline Lifespan & Up to 20 years & $\begin{array}{l}455 \mathrm{Mhz}, 2.45 \mathrm{Ghz}, \\
\text { or 5.8 Ghz }\end{array}$ \\
\hline Frequency & $902-928 \mathrm{MHz}$ & Continues \\
\hline Availability & Only in field of reader & $128 \mathrm{Kbytes} \mathrm{read} / \mathrm{read}$ \\
\hline Storage & 128 bytes read/read & \\
\hline
\end{tabular}

\section{B. Reader}

The interaction between the reader and tag is depends on type of tag used. The different tag carries different information about the specific target. The communication may be a simple ping or be more complex multi round protocol [6]. The reader will transmit a beam of impulses. This means gives commands to the tag and waiting for response. The reader will communicate with many tags at a certain time. So the reader need to perform a collision protocol to ensure that the communication conflict between the tags can be avoided.

\section{Database}

Database is the collection of the information that is organized so that easily to access, manage and update. In the propose system use the Microsoft SQL Server 2014 to store all the information for example staff information and tag information.

\section{Type of RFID}

1) RFID System Passive: RFID system-passive is the most popular technology used in the world. In RFID systempassive, the reader sends the radio signal to the tag. Then the tag is use the signal to activate and send energy or signal back to the reader [7]. This RFID passive-system ranges is limited by the power of the tags which is less than 10 meter. Passive tags do not have own power source and just need a tag chip and reader.

2) RFID System Active: In RFID system-active, tags have their own power supply and transmitter. The tags usually use the battery. RFID tags has their own signal to transmit the data or information on the microchips. The active tags are divided into the two types which is transponders and beacons. The function of the transponder is to conserve battery life. The transponders will active if and only if they receive a radio signal from the reader. If the transponder does not receive any radio signal, the tag will be deactivating and it will save battery energy. Beacons are used in Real Time Locating Systems (RTLS).

\section{3) Operating frequency}

TABLE II

RFID OPERATING FREQUENCY [8]

\begin{tabular}{|l|l|l|}
\hline Frequency Range & Frequency & $\begin{array}{l}\text { Passive read } \\
\text { distance }\end{array}$ \\
\hline Low Frequency (LF) & $120-140 \mathrm{KHz}$ & $10 \mathrm{~cm}-20 \mathrm{~cm}$ \\
\hline High Frequency (HF) & $13.56 \mathrm{MHz}$ & $10 \mathrm{~cm}-1 \mathrm{~m}$ \\
\hline $\begin{array}{l}\text { Ultra-High } \\
\text { Frequency (UHF) }\end{array}$ & $868-928 \mathrm{MHz}$ & 3 meters \\
\hline
\end{tabular}

\section{Low Frequency $(L F)$}

The LF frequency is the lowest frequency which is between $120 \mathrm{KHz}$ to $140 \mathrm{KHz}$ and usually RF system works at 125 $\mathrm{KHz}$ [8]. This range frequency provides a short read range between $10 \mathrm{~cm}$ to $20 \mathrm{~cm}$. LF read speed is the slowest compare to the other Frequency range but not very sensitive to the radio wave interference.

\section{High Frequency $(H F)$}

HF frequency is the intermediate frequency which is 13.56 $\mathrm{MHz}$ [8]. This range frequency provides more wide read range compare to LF between $10 \mathrm{~cm}$ to $1 \mathrm{~m}$. HF has the high data read rate but not good as LF in proximity to metals o liquid.

\section{Ultra-High Frequency (UHF)}

UHF has the high frequency compare to LF and HF frequency which is between $868-928 \mathrm{MHz}$ [8]. UHF has wide read range compare to $\mathrm{LR}$ and $\mathrm{HR}$ which is between three meter. UHF provide a high speed data read compare to other but UHF experience interference proximity to liquid and metal. 
4) Comparison with new system and existing system

TABLE III

COMPARISON BETWEEN THE PROPOSED SYSTEM AND EXISTING SYSTEM

\begin{tabular}{|c|c|c|c|c|}
\hline Detail & $\begin{array}{l}\text { Staff } \\
\text { attendance } \\
\text { using a } \\
\text { RFID } \\
\text { system } \\
\text { passive [9] }\end{array}$ & $\begin{array}{l}\text { Manual } \\
\text { punch } \\
\text { card } \\
\text { system } \\
\text { at } \\
\text { FSKTM } \\
{[10]}\end{array}$ & $\begin{array}{l}\begin{array}{l}\text { Outing } \\
\text { system } \\
\text { (KMNS) }\end{array} \\
{[11]}\end{array}$ & $\begin{array}{l}\text { System } \\
\text { propose }\end{array}$ \\
\hline $\begin{array}{l}\text { Characteristic } \\
\text { - Admin } \\
\text { module } \\
\text { - User } \\
\text { Module } \\
\text { - Output } \\
\text { display } \\
\text { - Control } \\
\text { functionalit } \\
\text { y } \\
\text { - RFID } \\
\text { technology }\end{array}$ & $\begin{array}{l}\text { Yes } \\
\text { Yes } \\
\text { Yes } \\
\text { Yes } \\
\text { Yes }\end{array}$ & $\begin{array}{l}\text { No } \\
\text { No } \\
\text { Yes } \\
\text { Yes } \\
\text { No }\end{array}$ & $\begin{array}{l}\text { Yes } \\
\text { No } \\
\text { Yes } \\
\text { Yes } \\
\text { No }\end{array}$ & $\begin{array}{l}\text { Yes } \\
\text { Yes } \\
\text { Yes } \\
\text { Yes } \\
\text { Yes }\end{array}$ \\
\hline $\begin{array}{l}\text { Programming } \\
\text { languages }\end{array}$ & $\begin{array}{l}\text { Visual } \\
\text { Basic.Net }\end{array}$ & & $\begin{array}{l}\text { Personal } \\
\text { Home } \\
\text { Page } \\
\text { (PHP) }\end{array}$ & $\begin{array}{l}\text { Visual } \\
\text { Basic .NET }\end{array}$ \\
\hline user Friendly & Yes & No & No & Yes \\
\hline Captcha code & No & No & No & Yes \\
\hline Audit Trail & No & No & No & Yes \\
\hline
\end{tabular}

Table 3 displays the comparison between the three related systems for producing useful comparative decision to develop the proposed system. In terms of use of the databases, all the existing systems use the database except for the manual punch card system. The characteristics studied are based on the administrator module and user module. All systems studied just have the administrator module. The administrator can manage and monitor all the process in the system.

All the systems have the control functionality. Based on the use of the RFID technology, all the systems use this technology accept the punch card system and Outing system KMNS. This is because manual punch card system only uses the card to record the employee attendance and outing system KMNS use the barcode to differentiate each student. Based on the programming languages, only two system use visual basic which is staff attendance using RFID system passive and the system propose. Outing system in KMNS used PHP as a platform.

All three existing systems do not have a captcha code and audit trail. These two components are important to protect the system from being attack by the unauthorized user. This two component will be implement to the propose system in order to protect the system from the security breach

\section{METHODOLOGY}

To complete this project, object oriented software development process is followed. There are seven phases in this object oriented software development process. There is requirement specification phase, system analysis phase, system design phase, implementation phase, testing phase, deployment phase and maintenance phase [12]. The details activities for each phase is shown in Table 4
TABLE 4

WORKFLOW ACTIVITIES

\begin{tabular}{|c|c|c|}
\hline Phases & Activities & Output \\
\hline $\begin{array}{l}\text { Requirement } \\
\text { Specification } \\
\text { Phase }\end{array}$ & $\begin{array}{l}\text { The users' requirements } \\
\text { are collected. }\end{array}$ & $\begin{array}{l}\text { List of detailed problem } \\
\text { and user requirement }\end{array}$ \\
\hline $\begin{array}{l}\text { System } \\
\text { Analysis Phase }\end{array}$ & $\begin{array}{l}\text { All the data collected are } \\
\text { analysed to identify the } \\
\text { best method to create a } \\
\text { new system that fulfil all } \\
\text { the user requirement. }\end{array}$ & $\begin{array}{l}\text { List of detail input and } \\
\text { output specification. }\end{array}$ \\
\hline $\begin{array}{l}\text { System Design } \\
\text { Phase }\end{array}$ & $\begin{array}{l}\text { Perform design the } \\
\text { interface design, classes } \\
\text { and database design }\end{array}$ & $\begin{array}{l}- \text { Data Flow Diagram } \\
\text { (DFD) } \\
-\quad \text { Entity Relationship } \\
\text { Diagram (ERD) } \\
-\quad \text { Unified Modelling } \\
\text { Language (UML) }\end{array}$ \\
\hline $\begin{array}{l}\text { Implementation } \\
\text { Phase }\end{array}$ & $\begin{array}{l}\text { Create and build the } \\
\text { database, user interface } \\
\text { and classes. }\end{array}$ & $\begin{array}{l}\text { Attendance system with } \\
\text { RFID }\end{array}$ \\
\hline Testing Phase & $\begin{array}{l}\text { Perform functional } \\
\text { testing each part of the } \\
\text { new system }\end{array}$ & Testing report \\
\hline $\begin{array}{l}\text { Deployment } \\
\text { Phase }\end{array}$ & $\begin{array}{l}\text { The system is installed } \\
\text { on the user computer }\end{array}$ & User feedback \\
\hline $\begin{array}{l}\text { Maintenance } \\
\text { Phase }\end{array}$ & $\begin{array}{l}\text { New system is } \\
\text { monitored and controlled }\end{array}$ & High performance system \\
\hline
\end{tabular}

\section{OBJECT ORIENTED ANALYSIS AND DESIGN}

\section{A. The Use Case Diagram}

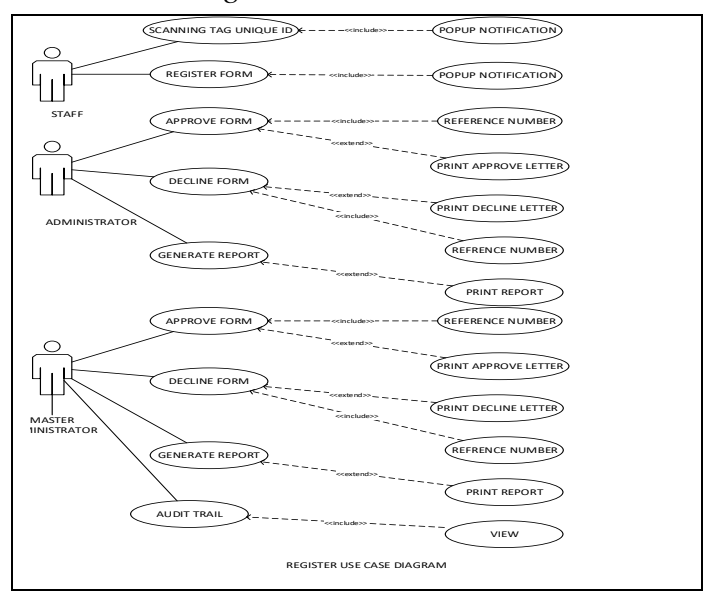

Fig. 2 Staff attendance use case diagram

The use case diagram shows there are three main users, namely staff, administrator, and master administrator (see Fig. 2). The common activities are describing as below.

1) Registration Form: The registration form is to register new staff. The staff fill up the form and submit for approval by the administrator. After the form is successfully submitted the form, the pop up notification is displayed on the monitor.

2) Approve Form: Approve form can only can be accessed by the administrator. The administrator needs to perform a task which is to approve the staff registration form. If the staff registration form is followed all the criteria needed, the administrator can approve the registration form 
3) Decline Form: Decline form only can be accessed by the administrator. Administrator needs to perform a task which is to decline the staff registration form. If the staff registration form does not follow all the criteria needed, the administrator can decline the registration form.

4) Generate Report: The administrator can generate a report about the staff registration at the end month or year. After generation of the report is complete, the administrator can print the report for the future action or present it to the dean.

5) Scanning Tag Unique ID: When the staff walk through the RFID reader with the tag, the staff needs to scan the tag. The system compares the unique id in the database to get the id information. Then the system displays a pop up notification at the monitor to inform that the attendance has been recorded.

6) Audit Trail: Master administrator can view and delete user activities when access to the system.

\section{B. Class Diagram}

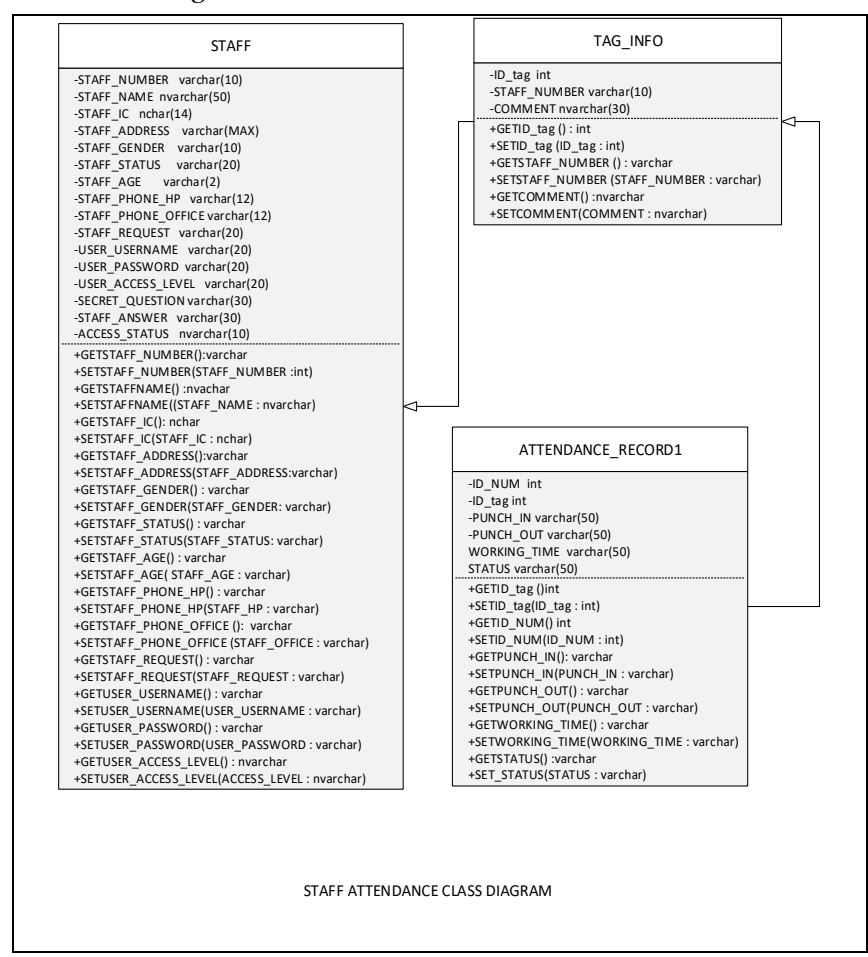

Fig. 3 Class diagram for staff attendance

Class diagram is static model that describes classes and their relationship of the system. Figure 3 shows the class diagram of the staff attendance. It shows that the proposed system has three class which is class STAFF, class TAG_INFO and ATTENDANCE_RECORD1.

\begin{tabular}{|c|c|}
\hline LOGIN_FAIL & ACTIVITY \\
\hline $\begin{array}{l}\text { ID int } \\
\text { USERAME_FAlLED nvarchar(50) } \\
\text { PASSWORD_FAlLED nvarchar(50) } \\
\text { COMMENT nvarchar(MAX) } \\
\text { TIME nvarchar(50) }\end{array}$ & $\begin{array}{l}\text {-ID int } \\
\text {-STAFF_NUMBER varchar(50) } \\
\text {-STAF_NAME nvarchar(50) } \\
\text {-ACTIVITY nvarchar(MAX) } \\
\text { TIME nvarchar(50) }\end{array}$ \\
\hline 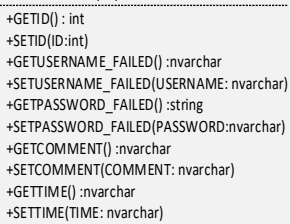 & $\begin{array}{l}\text { +GETID () : int } \\
\text { +SETID( ID: int) } \\
\text { +GEESTAFF_NUMBER () :vachar } \\
\text { +SETSAFF_NUMBER (STAF__NUMBER : vachar) } \\
\text { +GETSTAFF_NAME(): :vachar } \\
\text { +SETSTAF_NAME(STAFF_NAME : varchar) } \\
\text { +GETACTIVITY () : :nvachar } \\
\text { +SETACTIVITY (ACTIVITY : nvarchar) } \\
\text { +GETIME() : nvachar } \\
\text { +SETIME\{TIME : nvarchar\} }\end{array}$ \\
\hline \multicolumn{2}{|c|}{ AUDIT TRAIL CLASS DIAGRAM } \\
\hline
\end{tabular}

Fig 4: class diagram for Audit Trail

Figure 4 shows the class diagram for audit trail. It shows that the system has two class which is LOGIN_FAIL and ACTIVITY.

\section{Database Design}

The database design is important to give an initial overview of the tables of a database is developed. Specifications for each table described to explain in detail which is on an entity such as entity and attribute definitions involved and a description of each attribute. Figure 4 and Figure 5 shows the database design for the propose system.

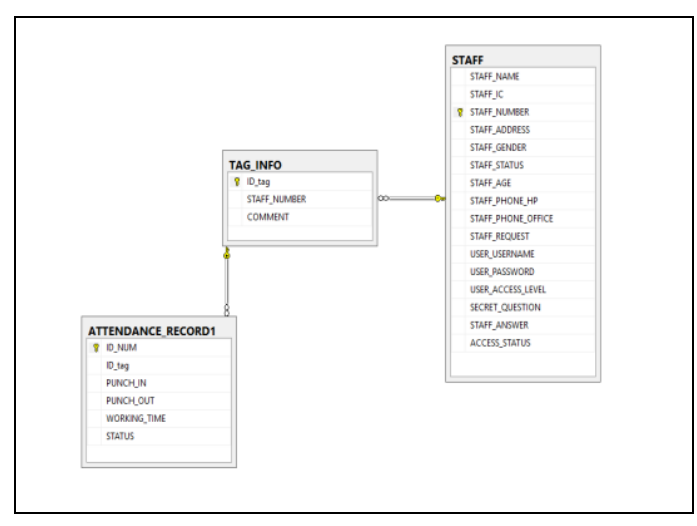

Fig. 4 Database design for the purpose system

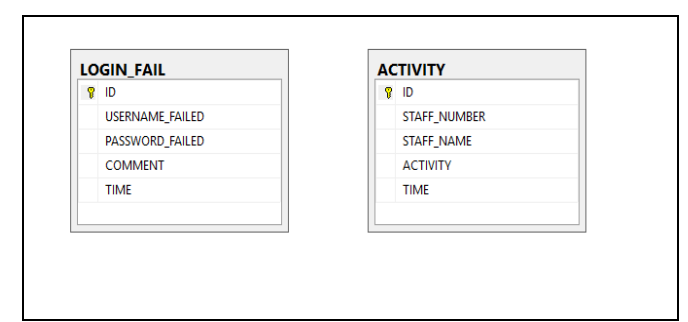

Fig. 5 Database design for Audit Trail 


\section{SYSTEM IMPLEMENTATION AND TESTING}

1) Creating and connecting database

Public Const cnString As String = ("Data
Source=DESKTOP-
87SQ4GUISQLEXPRESS;Initial
Catalog=STAFF_ATTENDANCE1;User
ID=sa;Password=thariq9694hebat")
Public Const cnString21 As String = ("Data
Source=DESKTOP-
87SQ4GUISQLEXPRESS;Initial
Catalog=AUDIT;User
ID=sa;Password=thariq9694hebat")

Fig. 6 Database Connection Command

Staff Attendance System used SQL Server 2014 for system database. This system used SQL command for connection between database and system interface. Fig. 6 shows the command used to connect database to the system.

\section{2) Development of record staff attendance}

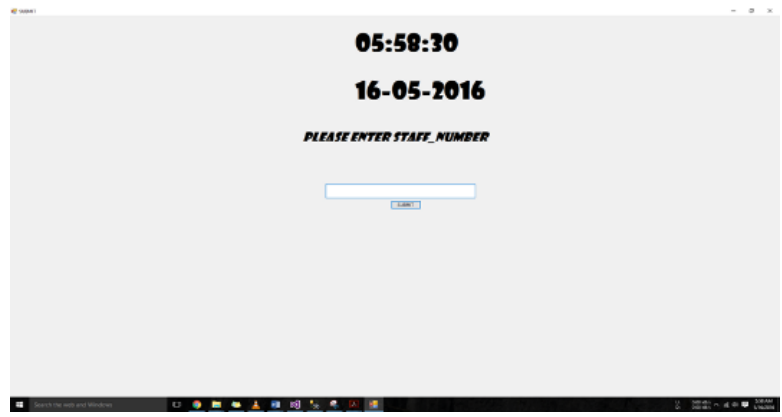

Fig. 7 Interface for record staff attendance

staff need to bring tag RFID every day to work. Staff needs to swipe their tags with a RFID reader so that the reader can collect the tag ID and send it to the system. Fig. 7 shows the interface for record staff attendance. Fig. 8 shows the code segmentation for record staff attendance.

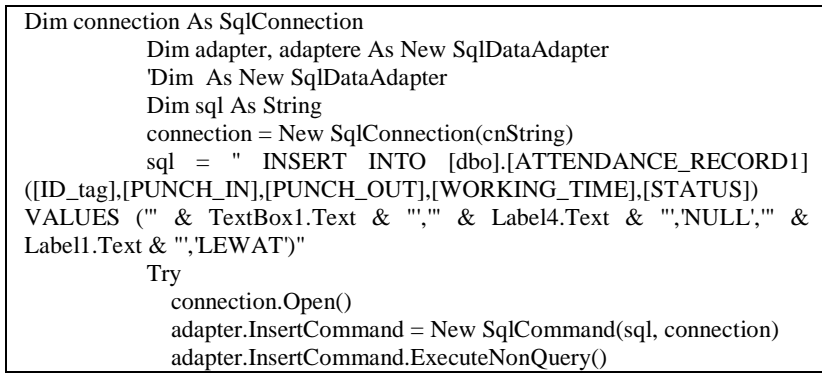

Fig. 8 Code segmentation for record staff attendance.

\section{3) Development of Login page process}

Staff Attendance System consists of three types of users which are master administrator, administrator, and staff. Fig. 9 shows the interface of user login. Users must enter username, password and code captcha before can access to the system. After users enter username and password successfully, the system automatically identifies the type of users and then redirect to the specific page.

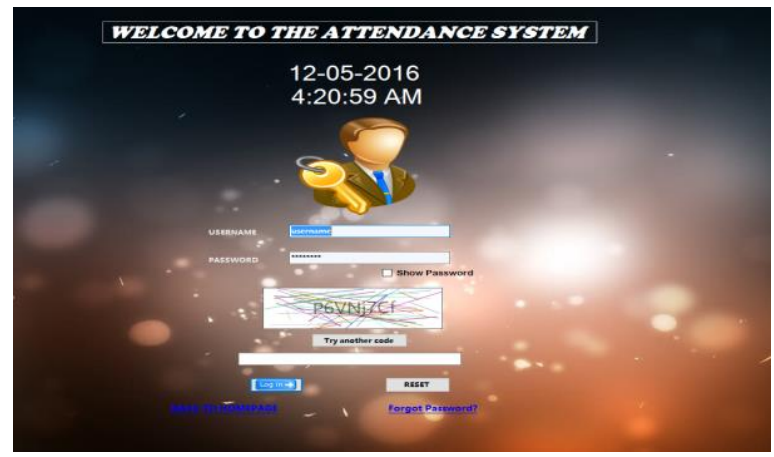

Fig. 9 Interface of user login

Fig. 10 shows the code segmentation for user to login to the system.

ElseIf txt_username.Text = username And Encrypt(txt_password.Text)
= password And level = "ADMINISTRATOR" And status =
"ACTIVE" And status = "TRUE" Then
'MsgBox("Variable sama dol :" \& TextBox2.Text)
ProgressBar1.Visible = True
MsgBox("LOGIN SUCCESS.LOGIN AS
ADMINISTRATOR", MsgBoxStyle.Information, "LOGIN")
Dim Obj As New ADMINISTRATOR
Obj.PassedText2 = txt_username.Text
Obj.Show()

Fig. 10 Code segmentation for user login

\section{CONCLUSIONS}

The proposed system basically achieved the objective which is to design, develop and test the record staff attendance using the RFID technology.

\section{1) System advantage}

The advantage of this proposed system are:

I. Provides the platform to staff FSKTM to record their attendance every morning and evening.

II. Staffs can view their attendance record at any time.

III. Allow faculty to monitor the staff attendance record.

IV. Master administrator can view the staff activity record if necessary.

V. System has a captcha code to differentiate between human and robot.

VI. System can block user account if the user failed enter correct password more than five times.

\section{2) System weaknesses}

This disadvantage of this proposed system:

I. System cannot record what data has been modified by the user

II. User cannot upload their profile picture

III. System do not have a session timer which is automatically logout if user do not perform any activity at certain time.

\section{3) recommendation for improvement}

Attendance record needs to enhance its functionality so the system can give more advantage to the user and can fight with other assessment system on the market.

The suggestion as follows: 
I. The system can record the data change if the user perform update, add, delete and modify activity.

II. System can allow user to set up their profile picture if needed.

\section{REFERENCES}

[1] K. Ahsan, H, Shah and P. Kingston, RFID Applications: An Introductory and Exploratory Study, IJCSI International Journal of Computer Science Issues, Vol. 7, Issue 1, No. 3, January 2010.

[2] M. Bhuptani, S. Moradpour, RFID Field Guide: Deploying Radio Frequency Identification Systems, Prentice Hall, 2005.

[3] N. C. Wu, M. A. Nystrom, T.R. Lin, and H. C. Yu, Challenges to Global RFID Adoption, Technovation 26, pp. 1317-1323, 2006.

[4] M. U. Malik, F. A. Khan, F. Malik and N. Ehsan, RFID Implementation and Security Concerns, $3^{\text {rd }}$ International Conference on Computer Science and Information Technology (ICCSIT), Vol 9, pp. 3-40, 2010
[5] S. Zuffanelli, P. Aguila, G. Zamora, F. Paredes, F. Martin and J. Bonache, A High-Gain Passive UHF-RFID Tag with Increased Read Range, Journal Sensors, Publisher Multidisciplinary Digital Publishing Institute, Vol 16, No 7, pp 1150, 2016.

[6] R. Weinstein, RFID: A Technical Overview and Its Application to the Enterprise, IT Prof., vol. 7, no. 3, pp. 27-33, May/Jun 2005.

[7] J. Landt, The History of RFID, IEEE Potentials, Vol. 24, pp. 8-11, 2005.

[8] M. Kaur, M. Sandhu, N. Moham, and P. S. Sandhu, RFID Technology Principles, Advantages, Limitations \& Its Applications, International Journal Computer Electronic Engineering, Vol. 3, No. 1, pp. 151-157, 2011.

[9] P. Sahoo, A RFID Based Attendance Tracking System, IOSR Journal of Environment Science, Toxicology and Food Technology (IOSRJESTFT), Vol. 2, Issue 2, pp. 12-17, Nov-Dec 2012

[10] Faculty Computer Science and Information Technology, University Tun Hussein Onn Malaysia, (2016). URL: http://www.uthm.edu.my.

[11] Kolej Matrikulasi Negeri Sembilan, (2016). URL http://www.kmns.matrik.edu.my.

[12] J. Keyes, Object Oriented Design (Software Engineering Series), Auerbach Publications, A CRC Press Company, 2003. 